\title{
Chest Drain Fall-Out Rate According to Suturing Practices: A Retrospective Direct Comparison
}

\author{
Rachelle Asciak Dinesh Addala Juzer Karimjee Maaz Suhail Rana \\ Stamatoula Tsikrika Maged Fayed Hassan Rachel Mary Mercer \\ Robert John Hallifax John Matthew Wrightson Ioannis Psallidas \\ Rachel Benamore Najib Mahboob Rahman
}

Oxford Pleural Unit, Oxford University Hospitals, Oxford, UK

\section{Keywords}

Pleura · Pleural catheter · Pleural effusion

\begin{abstract}
Background: Chest drains often become displaced and require replacement, adding unnecessary risks to patients. Simple measures such as suturing of the drain may reduce fall-out rates; however, there is no direct data to demonstrate this and no standardized recommended practice that is evidence based. Objectives: The study aimed to analyze the rate of chest drain fall out according to suturing practice. Methods: Retrospective analysis of all chest drain insertions (radiology and pleural teams) in 2015-2016. Details of chest drain fall out were collected from patient electronic records. Drain "fall out" was pre-hoc defined as the drain tip becoming dislodged outside the pleural cavity unintentionally before a clinical decision was taken to remove the drain. $\boldsymbol{R e}$ sults: A total of 369 chest drains were inserted: sutured ( $n=$ 106, 28.7\%; 44 male [41.5\%], median age 74 [interquartile range (IQR) 21] years), and unsutured ( $n=263,71.3 \% ; 139$ male [52.9\%], median age 68 [IQR 21] years). Of the sutured
\end{abstract}

\section{KARGER}

(c) 2018 S. Karger AG, Basel

E-Mail karger@karger.com

www.karger.com/res drains, 7 (6.6\%) fell out after a mean of 3.3 days (SD 2.6) compared to 39 (14.8\%; $p=0.04)$ unsutured drains falling out after a mean of 2.7 days (SD 2.0; $p=0.8$ ). Conclusions: Within the limits of this retrospective analysis, these results suggest that suturing of drains is associated with lower fallout rates.

(c) 2018 S. Karger AG, Basel

\section{Introduction}

Chest drains often fall out and require replacement, adding unnecessary patient risk and discomfort, prolonging hospital length of stay, and increasing workload on respiratory and radiology departments. In cases of malignant effusion, where drains are not re-inserted after falling out, pleurodesis may need to be deferred until fluid re-accumulation, delaying definitive treatment. Reported fall-out rates are variable, and the 2010 British Thoracic Society pleural disease guidelines [1] suggested auditing chest drain fall-out rates. In the British Thoracic Society national pleural procedure audit 2015 [2], 
9.2\% of chest drains fell out, and in the randomized controlled TIME1 trial where all drains were sutured, $42 \%$ of $12 \mathrm{~F}$ drains and $28 \%$ of $24 \mathrm{~F}$ drains were unintentionally displaced [3]. Simple measures such as suturing may reduce fall-out rates; although in many centers, suturing of chest drains is common practice, there is no direct data to demonstrate efficacy, and drains are still placed by a wide range of specialists, in whose practice stitches are not universally used. Reasons for not suturing drains include time-saving, lack of suturing skills, the perception that drain-dressings are adequate and that chest drains do not fall out when they are unsutured. This perception may be especially common in operators who are not responsible for the follow-up care of patients beyond the chest drain insertion procedure. In contrast, among operators familiar with suturing, the perception is that suturing is easy and does not add significant procedure time and serves as a further anchor beyond the usual drain dressings.

\section{Aim}

In our trust, chest drains inserted by the pleural team are sutured in place as the standard practice, while chest drains inserted by other teams (including radiology) are variably sutured. The aim of this study was to assess chest drain fall-out rates, and analyze factors associated with this negative clinical event, with chest drain fall out defined objectively and consistently.

\section{Methods}

All documented chest drain insertions in our trust in 2015 and 2016 were analyzed retrospectively. Details of chest drain fall out were collected from patient electronic records, including documentation on discharge summaries, requests for radiology procedures, and from radiology images. Drain "fall out" was pre-hoc defined on objective criteria as follows: the drain tip becoming dislodged outside the pleural cavity unintentionally before a clinical decision was taken to remove the drain.

The pleural team routinely use holding (anchoring) sutures (silk, 0.0) for chest drains, insert Seldinger (non-locking) chest drains of size $12 \mathrm{~F}$ mostly, and in addition use bio-occlusive or bespoke chest drain dressings (or both). The radiology team often do not suture chest drains, and insert chest drains of sizes 8-12 F, some of which are pigtail and mostly unlocked, and adhesive fabric dressings are usually used to strap the drain to the skin. A comparison of chest drain fall-out rates between sutured and unsutured chest drains was carried out.

Independent $t$ test or Mann-Whitney $\mathrm{U}$ test were used to compare continuous parametric and non-parametric variables, respectively, and chi-square or Fisher's exact test were used to compare categorical variables between the groups. As an audit of practice, ethics approval for this study was not required.

\section{Results}

A total of 369 chest drains were inserted: 106 (28.7\%) were sutured and 263 (71.3\%) were unsutured. Table 1 shows the underlying cause for the effusion, duration of chest drain in situ, number of locked drains, drain type and size, and ward patient was nursed on in the sutured and unsutured drain groups. Median overall duration of chest drains in situ was longer for sutured drains compared to unsutured drains (median 4 , interquartile range [IQR] 4 days compared to median 2 [IQR 3] days; $p=$ 0.0001 , Mann-Whitney U test). Twelve (11.3\%) unsutured drains were pigtail catheters, compared to 119 $(45.2 \%)$ of the sutured drains $(p<0.0001,2$-sided Fisher's exact test). Sutured drain sizes were 8-10 F $(n=3)$, $12 \mathrm{~F}(n=99)$, and $18-24 \mathrm{~F}(n=4)$, and unsutured drains were $8-10 \mathrm{~F}(n=111), 12 \mathrm{~F}(n=110)$, and insufficient data was available in 42 unsutured drains $(p<0.0001$, chi-square $76.5, \mathrm{df}=4$ ). There was insufficient data documented for the dressings of the unsutured drains to enable comparison of drain fall-out rates according to dressing types.

Of the drains that were sutured, 7 (6.6\%) fell out after a mean 3.3 (SD 2.6) days, whereas $39(14.8 \%$; $p=0.04$, 2 -sided Fisher's exact test) of the unsutured drains fell out after a mean 2.7 (SD 2.0) days ( $p=0.8$ ). None of the sutured drains that fell out were locked, 2 of the unsutured drains that fell out were locked ( $p=1.0,2$-sided Fisher's exact test). Despite unsutured drains being more likely to be smaller, there was no statistically significant difference in sizes of drains that fell out between the 2 groups $(p=$ $0.1, \chi^{2}=4, \mathrm{df}=2$ ). Also, despite patients with unsutured drains being more likely to be nursed on non-respiratory/ cardiothoracic surgery wards $(p<0.0001)$, there was no statistically significant difference in drain fall out between patients nursed on respiratory/cardiothoracic surgery wards and those nursed on other wards ( $p=1.0,2$-sided Fisher's exact test). There was also no statistically significant difference in underlying effusion cause $\left(p=0.9, \chi^{2}=\right.$ $0.7, \mathrm{df}=3)$.

\section{Discussion}

In the British Thoracic Society national pleural procedure audit in 2015 [2], 9.2\% of chest drains fell out. Overall, our data show a similar drain fall-out rate $(n=$ $46,12.5 \%)$, but a difference between unsutured chest drains (14.8\%) and sutured drains (6.6\%). This is likely to be an underestimate of the fall-out rate, as 
Table 1. Shows a comparison between sutured and unsutured chest drains

\begin{tabular}{|c|c|c|c|}
\hline & $\begin{array}{l}\text { Sutured drains } \\
(n=106,28.7 \%)\end{array}$ & $\begin{array}{l}\text { Unsutured drains } \\
(n=263,71.3 \%)\end{array}$ & $p$ value \\
\hline $\begin{array}{l}\text { Indication for chest } \\
\text { drain insertion }\end{array}$ & $\begin{array}{l}\text { - MPE }(n=52) \\
\text { - HF/hepatic hydrothorax }(n=7) \\
\text { - Empyema/para-pneumonic }(n=30) \\
\text { - Other }(n=17: \text { traumatic }[n=4], \\
\text { pneumothorax }[n=4], \\
\quad \text { post op }[n=2], \text { other }[n=7])\end{array}$ & $\begin{array}{l}\text { - MPE }(n=101) \\
\text { - HF/hepatic hydrothorax }(n=27), \\
\text { - Empyema/para-pneumonic }(n=76) \text {, } \\
\text { - Other }(n=59 \text { : post cardiac } \\
\quad \text { surgery } n=16)\end{array}$ & $\left(\chi^{2}=4.7, \mathrm{df}=3\right)$ \\
\hline $\begin{array}{l}\text { Duration } \\
\text { of chest drain in } \\
\text { situ, days, median (IQR) }\end{array}$ & $4(4)$ & $\begin{array}{l}2(3) \\
\text { NB: insufficient data in } 11 \text { patients }\end{array}$ & $\begin{array}{l}<\mathbf{0 . 0 0 0 1} \\
\text { (Mann-Whitney) }\end{array}$ \\
\hline Locked drains, $n(\%)$ & $5(4.7)$ & $27(10.3)$ & $\begin{array}{l}0.1 \\
(2 \text {-sided Fisher's } \\
\text { exact test })\end{array}$ \\
\hline Drain size & $\begin{array}{l}8 \mathrm{~F}(n=1), 10 \mathrm{~F}(n=2), \\
12 \mathrm{~F}(n=99), 18 \mathrm{~F}(n=3), \\
24 \mathrm{~F}(n=1)\end{array}$ & $\begin{array}{l}8 \mathrm{~F}(n=94), 10 \mathrm{~F}(n=17), \\
12 \mathrm{~F}(n=110), \\
\mathrm{NA}(n=42)\end{array}$ & $\begin{array}{l}<0.0001 \\
\left(\chi^{2}=76.5, \mathrm{df}=4\right)\end{array}$ \\
\hline Dressing type & $\begin{array}{l}\text { For pleural drains: } \\
\text { Bespoke }+ \text { bio-occlusive }(n=24) \text {; } \\
\text { bespoke }(n=7) \text {; bio-occlusive } \\
(n=13) \text {; NA }(n=62)\end{array}$ & Insufficient data available $(n=263)$ & NA \\
\hline Ward & $\begin{array}{l}\text { Respiratory/cardiothoracic } \\
(n=64,60.4 \%) \\
\text { Other }(n=42,39.6 \%)\end{array}$ & $\begin{array}{l}\text { Respiratory/cardiothoracic } \\
(n=75,28.5 \%) \\
\text { Other }(n=188,71.5 \%)\end{array}$ & $\begin{array}{l}<0.0001 \\
\left(\chi^{2}=32.7, \mathrm{df}=1\right)\end{array}$ \\
\hline Locked drains, $n$ & 0 & 2 & $\begin{array}{l}1.0 \\
(2 \text {-sided Fisher } \\
\text { exact test })\end{array}$ \\
\hline Size of drains & $10 \mathrm{~F}(n=1), 12 \mathrm{~F}(n=6)$ & $8 \mathrm{~F}(n=15), 10 \mathrm{~F}(n=3), 12 \mathrm{~F}(n=21)$ & $\begin{array}{l}0.1 \\
\left(\chi^{2}=4, \mathrm{df}=2\right)\end{array}$ \\
\hline $\begin{array}{l}\text { Underlying cause for } \\
\text { pleural effusion }\end{array}$ & $\begin{array}{l}\text { MPE }(n=3) \text {, infection }(n=3) \text {, } \\
\text { other }(n=1 \text { : post op }[n=1])\end{array}$ & $\begin{array}{l}\text { MPE }(n=21), \operatorname{HF}(n=1), \text { infection } \\
(n=14), \text { other }(n=3): \operatorname{PE}(n=1), \\
\text { hypoalbuminemia }(n=1), \\
\text { chylothorax }(n=1)\end{array}$ & $\begin{array}{l}0.9 \\
\left(\chi^{2}=0.7, \mathrm{df}=3\right)\end{array}$ \\
\hline Ward & $\begin{array}{l}\text { Respiratory/cardiothoracic } \\
(n=2), \text { other }(n=5)\end{array}$ & $\begin{array}{l}\text { Respiratory/cardiothoracic }(n=14) \text {, } \\
\text { other }(n=25)\end{array}$ & $\begin{array}{l}1.0 \\
(2 \text {-sided Fisher's } \\
\text { exact test })\end{array}$ \\
\hline
\end{tabular}

Values in bold represent values that reached statistical significance, with $p<0.05$. MPE, malignant pleural effusion; HF, heart failurerelated; post op, postoperative; IQR, interquartile range; NA, not available; df, degrees of freedom. 
the utilized audit system may not have captured this data if the drain fall-out event did not alter clinical management.

The results of this study suggest that a number of factors may be associated with reduced drain fall-out rate. This includes size of chest drain used and the routine use of suturing. The TIME1 study demonstrated a higher rate of unintentional displacement of $12 \mathrm{~F}$ chest drains compared to $24 \mathrm{~F}$ chest drains ( 42 vs. $28 \%$ ), where all chest drains were sutured in as part of the trial protocol [3]. This very high fall-out rate is likely related to the prospective (rather than retrospective) data collection, with prospective data being much more accurate in detection of complications with pre-hoc criteria.

Drain fall-out rate in this study was not related to duration of chest drain in situ; rather, sutured drains remained in situ for an overall longer median duration of time ( 4 days compared to 2 days, $p<0.0001$ ), and were less likely to fall out $(p=0.04)$. Neither was drain fall out related to the underlying cause for the effusion $(p=0.2)$. Patients with sutured drains were more likely to be nursed on cardiothoracic or respiratory wards $(p<$ 0.0001 ); however, drains that fell out were not more likely to be on non-respiratory/cardiothoracic wards than on other wards $(p=1.0)$. Overall, patients with sutured chest drains were more likely to have larger chest drains inserted $(p<0.0001$ for sizes of chest drains between sutured and unsutured chest drains); however, comparison of the sizes of the drains that fell out did not reveal a difference $(p=0.1)$.

Although this data is limited by its retrospective nature with a lack of data on types of dressings used for the unsutured chest drains, and we were unable to compare chest drain insertion techniques by the various operators who inserted the sutured and unsutured chest drains, these results suggest that suturing of drains may be associated with lower fall-out rates.

\section{Financial Disclosure and Conflicts of Interest}

There is no specific funding to declare for this study, however M. Hassan is a recipient of a long-term research fellowship from the European Respiratory Society - ERS LTRF 2016-7333; R.J. Hallifax is funded by a clinical training fellowship from the medical research council (MR/L017091/1); N.M. Rahman is funded by the NIHR Oxford Biomedical Research Centre.

There are no conflicts of interest to disclose with regards to this manuscript, for any of the authors.

\section{References}

-1 Du Rand I, Maskell N: Introduction and methods: British thoracic society pleural disease guideline 2010. Thorax 2010;65(suppl2):ii1-ii3.

$\checkmark 2$ Hooper CE, Welham SA, Maskell NA; British Thoracic Society: Pleural procedures and patient safety: a national BTS audit of practice. Thorax 2015;70:189-191.
Rahman NM, Pepperell J, Rehal S, Saba T, Tang A, Ali N, West A, Hettiarachchi G, Mukherjee D, Samuel J, Bentley A, Dowson L, Miles J, Ryan CF, Yoneda KY, Chauhan A, Corcoran JP, Psallidas I, Wrightson JM, Hallifax R, Davies HE, Lee YC, Dobson M, Hedley EL, Seaton D, Russell N, Chapman M, Mc-
Fadyen BM, Shaw RA, Davies RJ, Maskell NA, Nunn AJ, Miller RF: Effect of opioids vs NSAIDs and larger vs smaller chest tube size on pain control and pleurodesis efficacy among patients with malignant pleural effusion. The TIME1 randomised clinical trial. JAMA 2015;314:2641-2653. 